\title{
Intramolecular coordination of an alkene to a mixed dicyclopentadienyl benzyl zirconium cation studied by NMR spectroscopy
}

\author{
Mikhail V. Galakhov, Georg Heinz and P. Royo* \\ Departamento de Química Inorgánica, Universidad de Alcalá de Henares, Campus Universitario, E-28871 Alcalá de Henares, \\ Spain
}

Benzylation of $\left[\mathrm{Zr}\left(\eta^{5}-\mathrm{C}_{5} \mathrm{H}_{5}\right)\left\{\eta^{5}-\mathrm{C}_{5} \mathrm{H}_{4} \mathrm{SiMe}_{2}\left(\mathrm{CH}_{2} \mathrm{CH}=\right.\right.\right.$ $\left.\left.\left.\mathrm{CH}_{2}\right)\right\} \mathrm{Cl}_{2}\right] \quad 1$ yields $\left[\mathrm{Zr}\left(\eta^{5}-\mathrm{C}_{5} \mathrm{H}_{5}\right)\left\{\eta^{5}-\mathrm{C}_{5} \mathrm{H}_{4} \mathrm{SiMe}_{2}-\right.\right.$ $\left.\left.\left(\mathrm{CH}_{2} \mathrm{CH}=\mathrm{CH}_{2}\right)\right\}\left(\mathrm{CH}_{2} \mathrm{C}_{6} \mathrm{H}_{5}\right)_{2}\right] 2$, which reacts with either $\mathrm{B}\left(\mathrm{C}_{6} \mathrm{~F}_{5}\right)_{3}$ or $\left[\mathrm{Ph}_{3} \mathrm{C}\right]\left[\mathrm{B}\left(\mathrm{C}_{6} \mathrm{~F}_{5}\right)_{4}\right]$ to generate the same cation, $3^{+}$, which has been fully characterised by ${ }^{1} \mathrm{H},{ }^{13} \mathrm{C}$ NMR and ${ }^{1} \mathrm{H}$ DNMR spectroscopy.

It is generally accepted ${ }^{1}$ that a cationic 14-electron alkyl dicyclopentadienylzirconium complex of the type $\left[\mathrm{ZrCp}_{2} \mathrm{R}\right]^{+}$ stabilized by coordinative contact with a counter-ion $\left[\mathrm{R}_{-\mathrm{MAO}}{ }^{-} \quad(\mathrm{MAO}=\right.$ methylalumoxane $), \quad\left[\mathrm{RB}\left(\mathrm{C}_{6} \mathrm{~F}_{5}\right)_{3}\right]^{-}$or $\left[\mathrm{B}\left(\mathrm{C}_{6} \mathrm{~F}_{5}\right)_{4}\right]^{-}$provides a route to $\left[\mathrm{ZrCp}_{2} \mathrm{R}(\text { alkene })\right]^{+}$, a productive, active, cationic polymerization catalyst. Numerous synthetic studies involving the characterization of dicyclopentadienyl alkyl cationic group 4 metal complexes and their catalytic activity in Ziegler-Natta polymerization processes, have recently been reported. ${ }^{2}$ Many structural techniques have been used to investigate the formation of cationic species of this type and various theoretical methods ${ }^{3}$ have been applied to calculate the kinetic and thermodynamic parameters of their transition states and intermediate species.

However, in spite of the many attempts made, ${ }^{4}$ the crucial cationic $\mathrm{d}^{0}$ metal-alkene complex has only been observed and studied by $\mathrm{X}$-ray diffraction ${ }^{5}$ in the zirconium complex $\left[\mathrm{ZrCp}_{2}\left(\mathrm{OCMe}_{2} \mathrm{CH}_{2} \mathrm{CH}_{2} \mathrm{CH}=\mathrm{CH}_{2}\right)\right]^{+}$, in which the alkenic double bond shows a rather weak interaction with the metal center. The isolation of dimethyl titanium $6 a$ and zirconium ${ }^{6 b}$ complexes containing the 1-(but-3-enyl)-2,3,4,5-tetramethylcyclopentadienyl ligand has been reported, for which extensive low temperature NMR studies were unable to detect the alkenecoordinated metal complex. An yttrium pentenyl chelate has also been studied, ${ }^{7}$ where the exchange between the diastereotopic $\mathrm{C}_{5} \mathrm{H}_{4} \mathrm{Me}$ ligands is proposed to occur via rapid and reversible alkene dissociation followed by rate limiting inversion of the pyramidal $\mathrm{d}^{0}$ yttrium center. A related compound reported by Erker $^{8}$ was isolated by reaction of the butadiene zirconium complex $\left[\mathrm{ZrCp}_{2}\left(\mathrm{C}_{4} \mathrm{H}_{6}\right)\right]$ with $\mathrm{B}\left(\mathrm{C}_{6} \mathrm{~F}_{5}\right)_{3}$, resulting in the formation of a betaine system in which an anionic allyl system is coordinated to the dicyclopentadienyl zirconium cation.

In order to favour alkene coordination we decided to synthesize zirconium complexes containing the more electronwithdrawing di(methyl)(allyl)silyl(cyclopentadienyl) ligand to create a more acidic metal center with a slightly longer and more fluxional pendant chain, owing to the bulkier silicon atom.

As shown in Scheme 1 the dichloro complex $\left[\mathrm{Zr}\left(\eta^{5}\right.\right.$ $\left.\left.\mathrm{C}_{5} \mathrm{H}_{5}\right)\left\{\eta^{5}-\mathrm{C}_{5} \mathrm{H}_{4} \mathrm{SiMe}_{2}\left(\mathrm{CH}_{2} \mathrm{CH}=\mathrm{CH}_{2}\right)\right\} \mathrm{Cl}_{2}\right] \mathbf{1}$ was prepared $\dagger$ by reaction of the lithium salt of di(methyl)(allyl)silylcyclopentadiene $^{9}$ with stoichiometric amounts of $\mathrm{ZrCpCl}_{3}$.DME. Treatment of 1 with $\mathrm{MgBn}_{2} \cdot 2$ THF yielded the dibenzyl complex 2 .

NMR spectra recorded after mixing 1 equiv. of either $\left[\mathrm{Ph}_{3} \mathrm{C}\right]\left[\mathrm{B}\left(\mathrm{C}_{6} \mathrm{~F}_{5}\right)_{4}\right]$ or $\mathrm{B}\left(\mathrm{C}_{6} \mathrm{~F}_{5}\right)_{3}$ with 1 equiv. of complex 2 in $\mathrm{CD}_{2} \mathrm{Cl}_{2}$ at $-70{ }^{\circ} \mathrm{C}$ demonstrate the formation of the same 14-electron cationic species $\mathbf{3}^{+}$. Characteristic methylene resonances of $\mathrm{Ph}_{3} \mathrm{CCH}_{2} \mathrm{Ph} \quad\left(\begin{array}{ll}\delta & 3.90\end{array}\right)$ and non-coordinated $\left[\mathrm{PhCH}_{2} \mathrm{~B}\left(\mathrm{C}_{6} \mathrm{~F}_{5}\right)_{3}\right]^{-}(\delta 2.70$, br $)$ were observed, respectively.

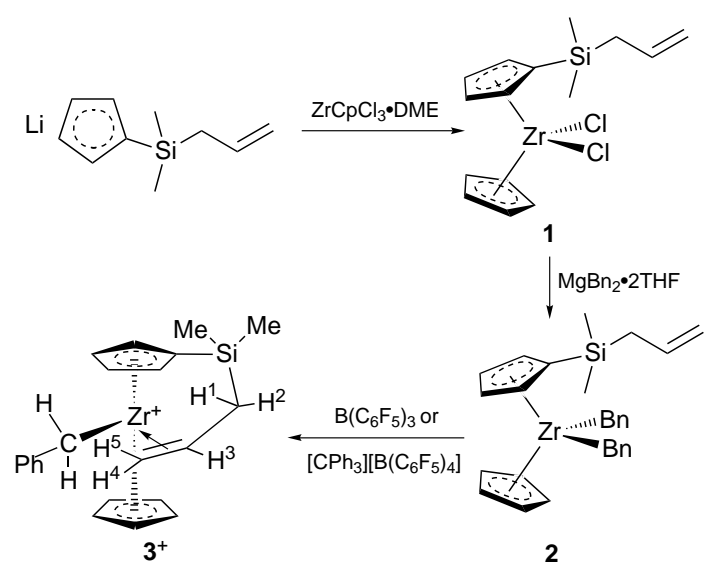

Scheme 1

Stabilization of this 14-electron cationic zirconium species is usually achieved by benzallylic coordination of the benzyl ligand, evidenced by the loss of the $C_{2 \mathrm{v}}$ symmetry of the phenyl ring and a substantial difference between the ${ }^{1} \mathrm{H}$ chemical shifts for the two methylenic protons $(\Delta \delta=2.80 \mathrm{ppm})$ observed $^{1 c}$ in the solid by X-ray analysis and in solution by NMR spectroscopy at low temperatures. However, this behaviour is not observed in the ${ }^{1} \mathrm{H}$ NMR spectra of $\mathbf{3}^{+}$at $203 \mathrm{~K}$ which shows $C_{2 \mathrm{v}}$ symmetry for the phenyl ring, an $\mathrm{AB}$ spin system $\left(\delta_{\mathrm{av}} 3.13\right.$, $\Delta \delta=0.27 \mathrm{ppm}$ ) for the two diastereotopic methylenic protons, two SiMe signals at $\delta 0.31$ and 0.59 , and four resonances at $\delta$ 5.74, 6.13, 6.35, 7.10 due to the CpSi ring protons, consistent with an asymmetric species. The ${ }^{1} \mathrm{H}$ NMR spectra of $\mathbf{3}^{+}$did not show a typical vinylic signal between $\delta 4.9$ and 5.6, but instead five new multiplets were observed at $\delta 1.81,2.05,2.13,2.78$, 7.30. Table 1 summarizes the chemical shifts and proton-proton coupling constants for the allyl chain protons of complexes 2 and $3^{+}$.

All of the spin-spin coupling constants for $\mathrm{H}^{3}, \mathrm{H}^{4}$ and $\mathrm{H}^{5}$ in complexes $\mathbf{2}$ and $\mathbf{3}^{+}$are very similar indicating that the $\mathrm{sp}^{2}$ character of the alkenic carbon atoms is not lost. However the $\mathrm{H}^{3}$ signal is shifted $\left[\Delta \delta=\delta\left(3^{+}\right)-\delta(2)\right]$ to low field $(\Delta \delta=+1.58 \mathrm{ppm})$ whereas the terminal $\mathrm{H}^{4}$ and $\mathrm{H}^{5}$ signals are displaced to high field $(\Delta \delta=-2.08$ and $-2.83 \mathrm{ppm}$, respectively); the $\mathrm{CH}_{2} \mathrm{Si}$ resonance is split and also displaced to low field $(\Delta \delta=+0.38,+0.46 \mathrm{ppm})$. Similar behaviour is
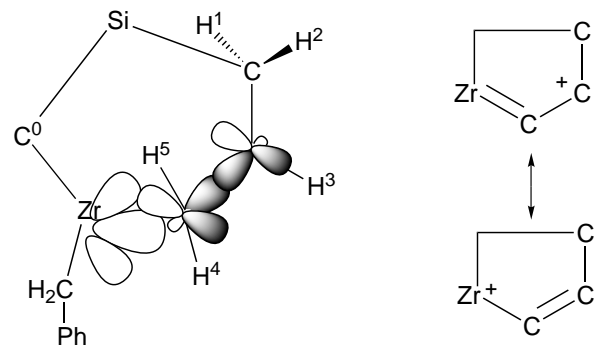

Scheme 2 

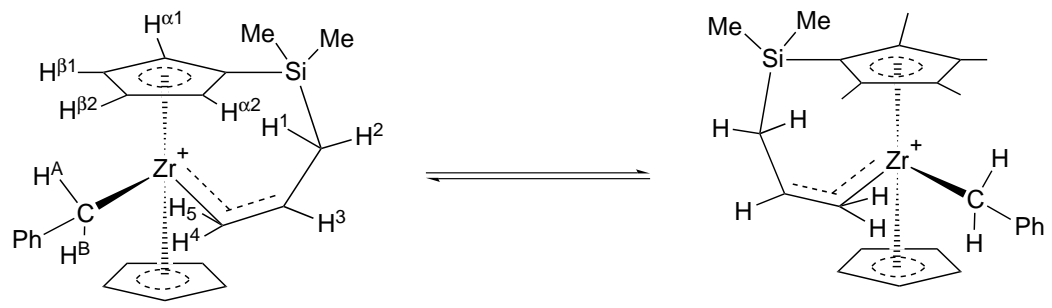

Scheme 3

Table 1 Important ${ }^{1} \mathrm{H}$ NMR data for complexes $\mathbf{2}$ and $\mathbf{3}^{+}$in $\mathrm{CD}_{2} \mathrm{Cl}_{2}$ at 203

\begin{tabular}{lll}
\hline & $\begin{array}{l}\delta(\mathrm{SSCC}, J / \mathrm{Hz}) \\
\text { Assignment }\end{array}$ & $\mathbf{2}$ \\
\hline $\mathrm{H}^{1}, \mathrm{H}^{2}$ & 1.66 & $2.05,2.13$ \\
& $\left(\mathrm{H}^{1}, \mathrm{H}^{2}-\mathrm{H}^{3} 8.0\right)$ & $\begin{array}{l}\left(\mathrm{H}^{1}-\mathrm{H}^{2} 11.5\right) \\
\left(\mathrm{H}^{1}-\mathrm{H}^{3} 10.5\right)\end{array}$ \\
& & $\left(\mathrm{H}^{2}-\mathrm{H}^{3} 5.2\right)$ \\
& 5.72 & 7.30 \\
$\mathrm{H}^{3}$ & $\left(\mathrm{H}^{3}-\mathrm{H}^{4} 10.5\right)$ & $\left(\mathrm{H}^{3}-\mathrm{H}^{4} 8.80\right)$ \\
& $\left(\mathrm{H}^{3}-\mathrm{H}^{5} 16.3\right)$ & $\left(\mathrm{H}^{3}-\mathrm{H}^{5} 16.5\right)$ \\
& 4.86 & 2.78 \\
$\mathrm{H}^{4}$ & $\left(\mathrm{H}^{4}-\mathrm{H}^{5} 3.8\right)$ & $\left(\mathrm{H}^{4}-\mathrm{H}^{5} 4.0\right)$ \\
& 4.83 & 1.81 \\
\hline
\end{tabular}

observed in the ${ }^{13} \mathrm{C}$ NMR spectra which show $\Delta \delta\left(C \mathrm{H}=\mathrm{CH}_{2}\right)=+36.2, \quad \Delta \delta\left(\mathrm{CH}=\mathrm{CH}_{2}\right)=-22.7$, $\Delta \delta\left(\mathrm{CH}_{2} \mathrm{Si}\right)=+2.8$ and $\Delta \delta\left(\mathrm{C}_{\mathrm{Cp}}\right)=-3.1 \mathrm{ppm}$. Displacement of the terminal alkenic $\mathrm{CH}_{2}$ moiety signals to high field is consistent with its coordination to the metal atom. This interaction is stronger than that reported by $\mathrm{Wu}$ and Jordan 5 and may be interpreted as the result of the interaction of the $\sigma$-bonding alkene orbital with the vacant $2 \mathrm{a}_{1}$ zirconium orbital and simultaneous overlapping of the HOMO $\pi$ alkene orbital with the vacant zirconium orbital of the same symmetry, $b_{2}$.

As shown in Scheme 2 these interactions result in delocalized electron density in the $\mathrm{Zr}-\mathrm{C}-\mathrm{C}$ system, similar to that observed for classical allyl cations, which is favoured by the known silicon effect ${ }^{9}$ and can be described in terms of the resonance structures of Scheme 2, where the terminal alkenic carbon is in a well known pentacoordinate situation. ${ }^{10}$ This description is consistent with the observed displacement of the $\mathrm{CH}=$ and $\mathrm{SiCH}_{2}$ resonances to low field and of $\mathrm{CH}_{2}=$ resonances to high field.

Variable temperature ${ }^{1} \mathrm{H}$ NMR spectra show dynamic behaviour which implies an interchange between the signals of the $\mathrm{CH}_{2} \mathrm{Ph}, \mathrm{CH}_{2} \mathrm{Si},\left(\mathrm{CH}_{3}\right)_{2} \mathrm{Si}$ and the $\mathrm{H}^{\alpha 1}-\mathrm{H}^{\alpha 2}$ and $\mathrm{H}^{\beta 1}-\mathrm{H}^{\beta 2}$ protons of the $\mathrm{C}_{5} \mathrm{H}_{4} \mathrm{R}$ ring, with little exchange in the $\mathrm{Zr}-\mathrm{C}-\mathrm{C}$ system. The assignment of the $\mathrm{H}^{\alpha 1}-\mathrm{H}^{\alpha 2}$ and $\mathrm{H}^{\beta 1}-\mathrm{H}^{\beta 2}$ signals was made from the results of saturation transfer experiments at $253 \mathrm{~K}$ and the spin-lattice relaxation time $T_{1}$ values measured at $-213 \mathrm{~K}\left(\mathrm{H}^{\alpha 1}: \delta 6.30, T_{1}=1.67 \mathrm{~s} ; \mathrm{H}^{\alpha 2}: \delta=6.10, T_{1}=1.61\right.$ $\left.\mathrm{s} ; \mathrm{H}^{\beta 1}: \delta=7.10, T_{1}=0.96 \mathrm{~s} ; \mathrm{H}^{\beta 2}: \delta=5.70, T_{1}=1.26 \mathrm{~s}\right)$. The signal at $\delta 7.10$ is assigned to the $\mathrm{H}^{\beta 1}$ proton located near the $\mathrm{C}_{5} \mathrm{H}_{5}$ moiety since is well known that proton relaxation times depend mainly on the number of adjacent protons and their distances. The $\mathrm{SiCH}_{2}$ resonance is observed at $263 \mathrm{~K}$ as one doublet ( ${ }^{3} \mathrm{~J} 8.3 \mathrm{~Hz}$ ) due to spin-spin coupling with $\mathrm{H}^{3}$. Coalescences of the $\mathrm{SiMe}_{2}$ and $\mathrm{CH}_{2} \mathrm{Ph}$ resonances are observed at $253 \mathrm{~K}$ with the same $\Delta G^{\ddagger}=11.7 \mathrm{kcal} \mathrm{mol}^{-1}(1 \mathrm{cal}=4.184$ J) calculated for the collapse of two equally populated singlets and for an AB spin system, respectively. This indicates that both are associated with a unique dynamic process involving interconversion between two enantiomers through a transition state with $C_{\mathrm{s}}$ symmetry.

The kinetic parameters for the process shown in Scheme 3 $\left(\log A=14.4 \pm 0.5, E_{\mathrm{a}}=13.4 \pm 0.54 \mathrm{kcal} \mathrm{mol}^{-1}, \Delta H^{\ddagger}=12.9\right.$ $\pm 0.53 \mathrm{kcal} \mathrm{mol}^{-1}, \Delta S^{\ddagger}=5.0 \pm 2.3 \mathrm{cal} \mathrm{K}^{-1} \mathrm{~mol}^{-1}$ and $\Delta G^{\ddagger} 298 \mathrm{~K}=11.4 \mathrm{kcal} \mathrm{mol}^{-1}$ ) obtained from ${ }^{1} \mathrm{H}$ DNMR data for exchange of the $\mathrm{SiMe}_{2}$ groups are consistent with an intramolecular process with negligible variation of entropy and are in good agreement with theoretical data reported by Bercaw and coworkers $^{11}$ for $\left[\mathrm{MCp}_{2} \mathrm{Me}\right]^{+}$.

Financial support of our work by DGICTY (Project PB92/0178-C) and CAM(I+D0034/94) is gratefully acknowledged. G. H. is grateful to the University of Alcalá for financial support and the Alexander von Humboldt-Stiftung for a fellowship.

\section{Footnotes and References}

* E-mail: proyo@inorg.alcala.es

$\dagger$ Complex 1 was isolated via treatment of a THF solution of $\left(\mathrm{C}_{5} \mathrm{H}_{5}\right) \mathrm{Si}$ $\mathrm{Me}_{2} \mathrm{CH}_{2} \mathrm{CH}=\mathrm{CH}_{2}(8.46 \mathrm{~g}, 42.0 \mathrm{mmol})$ with a $1.6 \mathrm{M}$ solution of buthyllithium in hexane $(28 \mathrm{ml}, 45.0 \mathrm{mmol})$ for $3 \mathrm{~h}$, and addition of the resulting solution to a suspension of $\mathrm{Zr}\left(\mathrm{C}_{5} \mathrm{H}_{5}\right) \mathrm{Cl}_{3}$. DME (14.9 g, $\left.42 \mathrm{mmol}\right)$ in THF (80 $\mathrm{ml}$ ) and stirring for $18 \mathrm{~h}$ at room temp. Complex 2 was prepared as a yellow solid (yield $84 \%$ ) by stirring a mixture of $1(853 \mathrm{mg}, 2.18 \mathrm{mmol})$ and $\mathrm{MgBn}_{2} \cdot 2 \mathrm{THF}(920 \mathrm{mg}, 2.62 \mathrm{mmol})$ in diethyl ether $(100 \mathrm{ml})$ for $18 \mathrm{~h}$ at room temp.

1 (a) R. F. Jordan, Adv. Organomet. Chem., 1991, 32, 3235; (b) H. H. Brintzinger, D. Fischer, R. Mülhaupt, B. Rieger and R. M. Waymouth, Angew. Chem., Int. Ed. Engl., 1995, 34, 1143; (c) M. Bochmann, J. Chem. Soc., Dalton Trans., 1996, 255.

2 X. Yang, C. L. Stern and T. J. Marks, J. Am. Chem. Soc., 1994, 116, 10015; L. Jia, X. Yang, C. Stern and T. J. Marks, Organometallics, 1994, 13, 3755; J. I. Amor, T. Cuenca, M. Galakhov and P. Royo, J. Organomet. Chem., 1995, 497, 127; L. Jia, X. Yang, A. Ishihara and T. J. Marks, Organometallics, 1995, 14, 3135; Y.-X. Chen, C. L. Stern, S. Yang and T. J. Marks, J. Am. Chem. Soc., 1996, 118, 12451; A. H. Horton, Organometallics, 1996, 15, 2675; T. L. Tremblay, S. W. Ewart, M. J. Sarsfield and M. C. Baird, Chem. Commun., 1997, 831; T. Cuenca, M. Galakhov, G. Jiménez, E. Royo, P. Royo and M. Bochmann, J. Organomet. Chem., 1997, in press; J. I. Amor, T. Cuenca, M. Galakhov, P. Gómez-Sal, A. Manzanero and P. Royo, J. Organomet. Chem., 1997, in press; L. Jia, X. Yang, C. L. Stern and T. J. Marks, Organometallics, 1997, 16, 842; A. D. Horton and A. G. Orpen, Organometallics, 1992, 11, 8; C. Pellecchia, A. Immirzi, A. Grassi and A. Zambelli, Organometallics, 1993, 12, 4473.

3 H. Weiss, M. Ehrig and R. Ahlrichs, J. Am. Chem. Soc., 1994, 116, 4919; T. K. Woo, L. Fan and T. Ziegler, Organometallics, 1994, 13, 2252; J. C. W. Lohrenz, T. K. Woo and T. Ziegler, J. Am. Chem. Soc., 1995, 117, 12793; P. Margl, J. C. W. Lohrenz, T. Ziegler and P. E. Blöchl, J. Am. Chem. Soc., 1996, 118, 4434.

4 J. Okuda, Nachr. Chem. Tech: Lab., 1996, 44, 135.

5 Z. Wu and R. F. Jordan, J. Am. Chem. Soc., 1995, 117, 5867.

6 (a) J. Okuda, K. E. du Plooy and P. J. Toscano, J. Organomet. Chem., 1995, 495, 195; (b) K. A. Butakoff, D. A. Lemenovskii, P. Mountford, L. G. Kuz'mina and A. V. Churakov, Polyhedron, 1996, 15, 489.

7 C. P. Casey, S. L. Hallenbeck, J. M. Wright and C. R. Landis, J. Am. Chem. Soc., 1997, 119, 9690.

8 B. Temme, G. Erker, J. Karl, R. Luftmann, R. Fröhlich and S. Kotila, Angew. Chem., 1995, 107, 1867.

9 J. B. Lambert, Tetrahedron, 1990, 46, 2677.

10 F. J. Fernández, P. Gómez-Sal, A. Manzanero, P. Royo, H. Jacobsen and H. Berke, Organometallics, 1997, 16, 1553.

11 E. P. Bierwagen, J. E. Bercaw and W. A. Goddard, III, J. Am. Chem. Soc., 1994, 116, 1481.

Received in Liverpool, UK, 8th July 1997; 7/04886F 